\title{
Christopher G. Weeramantry, Tread Lightly on the Earth: Religion, the Environment, and the Human Future
}

(Pannipitiya [Sri Lanka]: Stamford Lake, 2009), xvii, 338 pp.

ISBN: 978-955-658-190-4. US\$29.50

\section{Zarina Nalla International Institute of Advanced Islamic Studies (IAIS) Malaysia}

Most religions tell us that nature is the beautiful and perfect handiwork of God worthy of respect and protection. These principles should be integrated into international law if we are to address the current crisis facing humanity. Christopher Gregory Weeramantry discusses these ideas comprehensively in his book. The work received support from the World Future Council (WFC), an independent think-tank founded in 2007 in Hamburg, Germany, whose members are active in governmental bodies, civil society, business, science and the arts. The WFC's primary focus has been on the issue of climate change by promoting laws such as the renewable energy Feed-in Tariff.

Weeramantry, born in 1926 in Colombo, Sri Lanka, was a Justice of the Supreme Court of his country from 1967 to 1972 . He was also a Judge of the International Court of Justice (ICJ) from 1991 to 2000, and even its Vice-President from 1997 to 2000. In his capacity as Vice-President he presided over several important cases before the ICJ, including a case on the illegality of the use (and threatened use) of nuclear arms. He is currently Emeritus Professor at Australia's Monash University.

At an international conference in Kuala Lumpur in 2010, Weeramantry, who is not a Muslim, mentioned that the title of his book was in fact inspired by a qur'ānic verse, "the faithful servants of the Beneficent [i.e. God] are those who tread upon the earth gently" (25:63), which to him clearly illustrates that to preserve life man must be moderate in the way he uses natural resources and not deplete them. However, values enshrined in modern life have dangerously focused only on the present and ignored the importance of protecting the environment for future generations. Short-term perspectives, get-rich-quick schemes, and rapid economic growth have cost us dearly, he laments in his book. Indeed, he dedicates the book to "future generations whose inheritance needs urgent protection". The eleven chapters describe the current environmental crisis, the problematic thought frames, the Assisi Declaration of 1986, and the perspectives of the five major religions - Christianity, Islam, Buddhism, Hinduism, and Judaism - on the environment.

Weeramantry explains that when international law sought independence from common core teachings of the world's greatest religions, it essentially "deprived itself of an important source of strength and inspiration" and created a secular paradigm which ushered in the alliance of state and commercial enterprise. This bonding often legitimised the pursuit of profit and left it unchecked. Moral and 
ethical constraints were minimal. However, multiculturalism which characterises today's world has paved the way for great religions to engage and discuss their common values. In fact, he argues convincingly, what unites religions is far more important than what divides them. This significant bond and the mere fact that the majority of the world's 6.7 billion inhabitants are followers of some kind of religion, offer a powerful force that can change attitudes and address the environmental crises. Critics may question or even ridicule this conviction that religions will 'save the day' by galvanising their followers to halt and reverse environmental damage. How can this be possible, they ask, given that some of the bloodiest wars in history were waged in the name of religions?

Weeramantry's prescription, however, is not without a firm basis. He explains that it was only in the twentieth century that scientists realised nature's limited capacity to absorb pollutants and to provide resources. This meant that continuous human consumption impacted the availability of earth's assets. The crisis was so grave that in 1992 the Union of Concerned Scientists issued a warning that "[h]uman beings and the natural world are on a collision course". Scholars began turning to other disciplines for answers to the unprecedented problem that quickly assumed legal, moral, and religious dimensions which were downplayed during the years of industrialisation and rapid economic development. They studied how ancient wisdoms had protected and nurtured the relationship between humans and their environmental home. During that time, scholars began to discover and appreciate the deep environmental wisdom embedded in the teachings of the great religions. Prudence in human conduct towards their surroundings was being prescribed. No amount of scientific knowledge has taught humans how to create even the tiniest seed and the crisis has taught man to be humble and to realise that the environment is not an object of exploitation.

The fundamentals of the human relationship with the environment crosses all cultural and religious boundaries, as Weeramantry explains. To list just a few points made by him: there is an intricate interrelationship between humanity and the component elements of the environment and in the theistic religions with God Himself; neglect of duties of trusteeship will attract punishment and adverse consequences; there is a duty to avoid waste and cruelty to animals. These principles should guide decision-makers in national lawmaking and regional policy frameworks. It is undeniable that a spiritual awakening has begun internationally. The author illustrates this by highlighting notable activities such as a series of ten conferences on the theme of 'Religions of the World and Ecology' organised by the Harvard Divinity School between 1996 and 1998. Moreover, there is a study on 'Religion and Ecology: Can the Climate Change?' launched by the American Academy of Arts and Sciences. 
Weeramantry's book highlights twelve problematic worldviews which focus on profit-making in the shortest time frame and are responsible for the unbalanced approach humans have adopted toward the environment. Among them are:

- the erroneous idea that only a privileged nation or group is entitled to a disproportionate share of resources;

- the belief that one's own national sovereignty must be preserved and advanced at all costs;

- the importance of rights over duties;

- that scientific views must be quantifiable; and

- that humans are the only owners of all the resources of the planet.

Moreover, the author is advocating a change of focus from short-term to long-term perspectives which all religions converge on and which should be as follows:

- intergenerational equities

- avoidance of luxury and ostentation

- simple living

- concern for one's neighbour

- the emphasis on duties rather than rights

- the stress on spiritual rather than materialistic views

- notions of trusteeship of earth resources

- discouragement of the pursuit of wealth and power

- avoidance of waste, and

- the stress on the interests of the community rather than the rights of the individual.

Study of the innate relation between core religious principles and the protection of the environment was only begun systematically by scholars in the early twentieth century. A key development in this direction was the Assisi Declarations of 1986 - named after St Francis of Assisi ${ }^{1}$ (d. 1226), one of the greatest spiritual figures of Christianity, who too was concerned about harmony with the natural order - an event which marked the twenty-fifth anniversary celebrations of the Worldwide Fund for Nature, and which essentially drew upon the teachings of Hinduism, Judaism, Islam, Christianity, and Buddhism. The Declaration rests on the words of Father Lanfranco Serrini, the convenor of the event: "We are convinced of the considerable value of our respective traditions and of what they can offer to re-establish ecological harmony; but at the same time, we are humble enough to desire to learn from each other. The very richness of our diversity lends strength to our shared concern and responsibility for our Planet Earth." 
There is thus a desperate and urgent need to integrate ancient wisdoms and the core teachings of great religions into the body of international law and its practical applications. Weeramantry also observes, however, that the many multi-religious conferences that have been organised did not affect the desired changes, as recommendations and results of the deliberations were rarely translated into laws that could be implemented. Interestingly, he states (p. 248) that any "modern legal system seeking to conserve earth resources, protect the environment, and safeguard the human future would benefit from the wealth of principles, concepts and procedures to be found in Islamic teachings. The range of this knowledge and its practical usefulness in the environmental field are little known, even to many Muslims, and even more so to non-Muslims. Indeed, it is little known even in the academic world. It is of vital importance that this knowledge should be more widely disseminated."

In sum, this is a very rewarding book which also contains valuable recommendations for policy-makers in terms of spiritual resources for sustainable development and handling of the world's natural resources.

\section{Note}

1. On St Francis' commitment to interfaith dialogue, especially with the world of Islam, see also the fascinating book by Pulitzer Prize winner Paul Moses, The Saint and the Sultan: The Crusades, Islam, and Francis of Assisi's Mission of Peace (New York: Doubleday, 2009), and the review of it by Christoph Marcinkowski in Islam and Civilisational Renewal 1, no. 3 (April 2010), 539-41. 